\title{
Five Important Considerations for the Development of Anti- corruption Education in Malaysia for Young People
}

Lim Mengzhen, Eliza Berezina, Wan Munira Wan Jaafar, Azlina Mohd Khir, Hanina H. Hamsan

To Link this Article: http://dx.doi.org/10.6007/IJARBSS/v11-i11/11777

DOI:10.6007/IJARBSS/v11-i11/11777

Received: 04 September 2021, Revised: 06 October 2021, Accepted: 25 October 2021

Published Online: 19 November 2021

In-Text Citation: (Mengzhen et al., 2021)

To Cite this Article: Mengzhen, L., Berezina, E., Jaafar, W. M. W., Khir, A. M., \& Hamsan, H. H. (2021). Five Important Considerations for the Development of Anti-corruption Education in Malaysia for Young People. International Journal of Academic Research in Business and Social Sciences, 11(11), 2583-2596.

Copyright: (c) 2021 The Author(s)

Published by Human Resource Management Academic Research Society (www.hrmars.com)

This article is published under the Creative Commons Attribution (CC BY 4.0) license. Anyone may reproduce, distribute, translate and create derivative works of this article (for both commercial and non0-commercial purposes), subject to full attribution to the original publication and authors. The full terms of this license may be seen

at: http://creativecommons.org/licences/by/4.0/legalcode

Vol. 11, No. 11, 2021, Pg. $2583-2596$

Full Terms \& Conditions of access and use can be found at http://hrmars.com/index.php/pages/detail/publication-ethics 


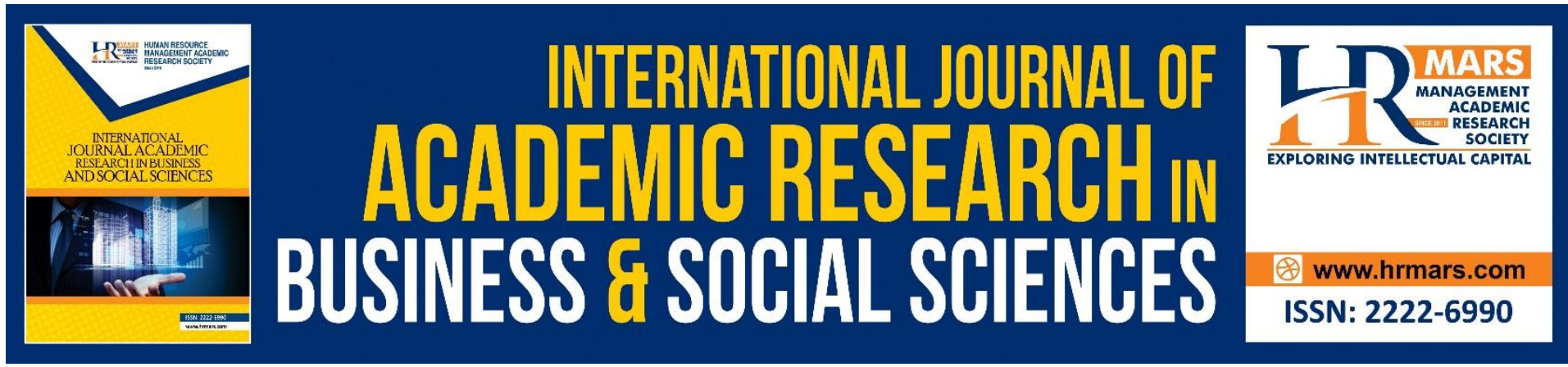

\title{
Five Important Considerations for the Development of Anti-corruption Education in Malaysia for Young People
}

\author{
Lim Mengzhen ${ }^{1 \& 2}$, Eliza Berezina ${ }^{2}$, Wan Munira Wan Jaafar ${ }^{1}$, \\ Azlina Mohd Khir ${ }^{1}$, Hanina H. Hamsan ${ }^{1}$ \\ ${ }^{1}$ Department of Social and Development Sciences, Faculty of Human Ecology, Universiti \\ Putra Malaysia, ${ }^{2}$ Department of Psychology, School of Medical and Life Sciences, Sunway \\ University \\ Email: wanmunira@upm.edu.my
}

\begin{abstract}
Anti-corruption education is important in curbing corruption behavior. However, there is limited evidence about what should be designed into the anti-corruption curriculum for young people. Hence, this study intends to make suggestions about the development of anticorruption education in Malaysia based on Theory of Social Representation. A survey to explore young people's lay representation toward corruption was carried out. 232 respondents between 18 to 33 years old $(M=19.79, S D=2.65)$ participated in this crosssectional survey performed in Malays Language and translated into English for report purposes. The lay representation of the terms "corruption" was obtained using the free association and the rank-frequency technique. The result suggests five important considerations for the development of anti-corruption education: (1) educate people about the concept of corruption that includes not only money exchange; (2) continue to provide examples of integrity and legal practices in politics; (3) educate people about all types of corruption, (4) emphasize that corruption is not acceptable regardless of any situation or circumstances and (5) educate people about the effects of corruption. This suggestion could be used by the government, stakeholders, schools, and non-profit organizations who are interested in educating the public or creating anti-corruption awareness among young people in Malaysia.
\end{abstract}

Keywords: Anti-Corruption Education, Bribery, Lay Representations, Social Representation, Youth

\section{Introduction}

Corruption is one of the most serious social problems faced by Malaysia (Satar, 2018). Over the years, researches has been done to find solutions to curb corruption (e.g. Haw et al., 2020; Kasim \& Hoesni, 2021). Besides that, the government also allocated funding for the Malaysian Anti-Corruption Commission (MACC) as the sole agency to fight corruption, a national anticorruption plan, two government transformation programmes and national integrity plan (Muhamad \& Gani, 2020). However, most of the efforts to curb corruption failed to improve 
the situation in an expected manner (Muhamad \& Gani, 2020). Learning from the east, Japan's success in managing corruption can be attributed to their investment in anti-corruption education (Assegaf, 2017). Therefore, there is still a high demand for anti-corruption education that is widely supported by the general public who is forcing the government to look into the matter (Bernama, 2020; Lee, 2018). Although research has been carried out to explain corruption-related matters (e.g. Muhamad \& Gani, 2020), there have been few empirical investigations about the syllabus of anti-corruption education. As educational matters are usually controlled (e.g. syllabus, funding) by the government (Gill \& Berezina, 2020), developing a syllabus without proper research might result in waste of public funds and failure. Without formal anti-corruption education to date, we must first explore how much our young people understand corruption in order to design a syllabus that complements the current knowledge and understanding. Hence, this research intends to explore how young people understand and make sense of what is corruption.

Understanding is fundamental to act. However, corruption is difficult to define (Kollmannová, 2013) as corruption incidents could be interpreted differently for different people from time to time. Before the 2013 election in Malaysia, Mr. Najib Razak, the fifth Prime Minister of Malaysia, received approximately $\$ 681$ million into his private bank account (Wright \& Hope, 2018). What words or phrases come to your mind after knowing this news? If it is the word "corruption", you might be wrong as he explained that it was a "donation" from Saudi Arabia's royal family (Ngui \& Wright, 2016). As a politician, he has grassroots supporters who might support this interpretation, resulting in his great victory in the Pekan parliamentary seat during the last election (Suruhanjaya Pilihan Raya Malaysia, 2021). This ambiguity in the interpretation of corruption does not happen only in a political context.

In other real-life situations, people may also have different understanding of what corruption is. For example, giving flowers to our beloved teacher during teacher's day. Is this an act of appreciation or corruption? Most people may rationalize it by interpreting it as a form of appreciation instead of corruption. Appreciation is an act of reciprocity and it is one of the main characteristics of Asian values. People give presents to teachers, clients, or government servants as a token of appreciation and to show respect (Upton-McLaughlin, 2013). In Japan, exchanging gifts seems to be necessary for business transactions (Lee \& Yoshihara, 1997). However, Alatas (1991) described it as investive corruption that is defined as the offer of goods or services that has no direct link to a particular favour but in anticipation of future occasions when the favor will be required. Only recently, the government and businesses started a "no gift policy" (see Muhiudeen, 2018) as this may be interpreted as a form of corruption. With all the ambiguity in defining corruption, exploring people to date understanding of corruption could help to design a better curriculum to curb corruption.

This objective could be achieved by using the structural approach under the Theory of Social Representation (TSR) to explore how young people lay represented corruption (Moliner \& Abric's, 2015) . Lay representations are a system of communication and social influence that constitutes the social realities of different groups in society (Sammut \& Howarth, 2014, p. 1799). As the social realities are shared by many people, they can affect people's behavior (Bidjari, 2011). Lay representation is common-sense knowledge worked out by people in everyday communication to provide meaning to different objects, phenomena, events that 
are new, strange, unknown, and threatening (Dvoryanchikov et al., 2014). Once lay representation is established, we will act upon it (Voelklein \& Howarth, 2005).

The usage of TSR to study corrupt behaviour is not new. Social Representation study in Indonesia revealed that corruption is represented by people, money, steal or take, harmful and country (Abraham \& Pradipto, 2016); In Portugal, corruption is not only represented by bribery but other behaviors as well (Sousa, 2008); "corruption, in general", is represented by practices and motives that reflect a moral judgment, and by illegal groups and activities (Poeschi \& Ribeiro, 2015) and Steklova \& Steklov (2018) found that youths associated the term corruption with bribe, money, power, the official and theft. However, no similar research has been found that studied young people in Malaysia. In the current work, we explore young people's lay representation of corruption based on TSR to make suggestions about anti-corruption education syllabus.

\section{Methods}

\section{Ethical Considerations}

This research was approved by the University Research Ethics Committee, reference SUREC 2020/083.

\section{Study Design \& Data Collection}

This is a cross-sectional survey designed study. The lay representations of the terms "corruption" was obtained using the free association and the rank-frequency technique, as suggested by (Moliner \& Abric, 2015). This is a common method used in studies to understand the semantic content of lay representation (Chundu et al., 2021).

\section{Respondents}

Data was collected using opportunity sampling from 232 respondents between 18 to 33 years old ( $M=19.79, S D=2.65) .53(22.8 \%)$ were male, and 179 (77.2\%) were female. This sample size for social representation study can have a minimum sample of 106 (Dvoryanchikov et al, 2014), we deemed the sample size for this study is sufficient. The inclusion criteria were Malaysians, 18 years old and above and currently residing in Malaysia. Most of the respondents, $n=199$ (85.8\%) are college or university students.

\section{Measure}

To understand the lay representation of "corruption", respondents were asked "Think about CORRUPTION. What words or phrases come to your mind? Please, write five words or phrases." The words and phrases written are the elements of lay representation. This research was carried out in the Malays language and the report is written in English for knowledge-sharing purposes. Translation from Malays Language and English was done using the "Forward and backward" translation technique (Brislin, 1970; Kamaluddin et al., 2017) by coders proficient in both languages.

\section{Procedures}

Upon implying consent to participate in this study via survey platform Qualtrics, respondents type the words or phrases that come to their mind in sequence in Malay's language. Respondents were then asked to answer demographic questions before exiting the study. Three analyses were done, (1) Content coding was done to recode words or phrases of the 
same meaning belonging to the same semantic class and translated into English. Software Iramuteq was employed to run the (2) similarity and (3) prototypical analysis. The result was presented and discussed.

\section{Content Coding}

Words or phrases of the same meaning belonging to the same semantic class were recorded. For example: "wang" and "duit" (in Malay'slanguage) were recoded into "money". The initial recording was done by the researchers. After that, 10 independent coders were shown original and recorded the word or phrase and indicated agreement on it. The average pairwise percentage was $99.7 \%$. Next, all the words were translated. Six independent participants who self-declared to be native Malay language speakers were recruited for forward translation and another three were recruited for backward translation purposes. The software Iramuteq was used to perform the prototypical analysis and to reveal the content of lay representations (Chundu et al., 2021).

\section{Similarities Analysis}

Similarity analysis is a technique based on mathematical graph theory (Danermark et al., 2014). It is often used in lay representation because it helps us to understand the most important elements in lay representation (Chundu et al., 2021); how its internal structure was organized (Bouriche, 2003 as cited in Ferrara \& Friant, 2016; Polli et al., 2021); and most importantly it helps in describing the relationship between the elements (Mondragon et al., 2021). Iramuteq software could be used to carry out similarity analysis by calculating the frequency of co-occurrences. The data will be presented in a tree-shaped graph that illustrates the elements that "go together" (Polli et al., 2021). The nodes in the graph represent the frequency of the elements, where bigger nodes indicate the higher frequency reported in that cluster (Chundu et al., 2021). High frequencies are the fundamental of the representation and hold the representation together due to greater connection with other elements (Bales \& Johnson, 2006). The lines between the nodes illustrate the relationship between elements, where thicker lines indicate a higher frequency or stronger relationship.

\section{Prototypical Analysis}

Verges's (1992) prototypical analysis is used to categorize respondents' social representation into the central core and periphery system (Dvoryanchikov et al., 2014). This method measures two parameters, association frequencies, and rank of their appearance. The appearances that come first indicate its importance level. The result of the analysis usually presents in a $2 \times 2$ table, see Table 1 (Chundu et al., 2021).

Box 1, the central core elements include elements with high frequency and high importance levels. These are the elements that appear in the mind of the respondents when asked about the main variables. The central core system consists of words that help us to manage the meanings associated with the phenomena and strengthen non-negotiable beliefs. It consists of elements that are stable and agreed upon by most of people in the group. Words that formed the central core system are deeply rooted in the collective memory of the social group (Orosz, 2010). It consists of just a few unconditional beliefs that allow one to define the group's values, norms, and history. Words in the central core system are also stable over time. The primary function of the peripheral system is to protect the central core system (Moliner \& Abric, 2015). It consists of elements that are unique for each group member. Words that 
formed the peripheral system are more anchored in momentary reality, unstable, developing, and not concrete elements. It is closer to individual memories. Because of these characteristics, it allows individuals to integrate potential contradiction, new information without the need to transform the central core system.

There are two main peripheral groups, proximal peripheral systems (see Box 2 and 3 in Table 1), and far peripheral systems (see Box 4 in Table 1).

Box 2, the first periphery represents words that have high frequencies and low importance levels. Words in this element are not easily evoked and changes are influenced by the environment and everyday experiences (Chundu et al., 2021). Box 3, the contracting elements, which includes words that have low frequencies but high in their importance level. The associations in this box are easily evoked but not frequent. The words in this box indicate a subgroup that prioritizes certain categories that are different from the majority (Chundu et al., 2021). Box 2 and 3 are also considered as potential change zone. Potential change zones could potentially bring the changes to the central system and change the representation as a result of it (Granhag et al., 2017). Box 4 consists of second periphery elements; words that appeared in this box are low in frequencies and low in importance level. Words listed in this box are the least useful in defining lay representation (Chundu et al., 2021).

\section{Results}

\section{Content Coding}

A total of 1160 words or phrases were collected and were classified into 366 concepts. Words and phrases that had less than $5 \%$ frequency were excluded from the analysis (Dvoryanchikov et al., 2014). Table 1 shows the concepts that reach the threshold to be included in the structure of lay representations of corruption. There are 19 elements of lay representations for corruption. 
INTERNATIONAL JOURNAL OF ACADEMIC RESEARCH IN BUSINESS AND SOCIAL SCIENCES Vol. 11, No. 11, 2021, E-ISSN: 2222-6990 @ 2021 HRMARS

Table 1. Frequencies of 19 elements included in the lay representations of corruption

\begin{tabular}{|c|l|c|c|}
\hline \multicolumn{1}{|c|}{ Element } & $\mathrm{n}$ & $\%$ \\
\hline 1 & money & 156 & 26.17 \\
\hline 2 & dishonest & 61 & 10.23 \\
\hline 3 & politics & 53 & 8.89 \\
\hline 4 & illegal & 44 & 7.38 \\
\hline 5 & cheat & 36 & 6.04 \\
\hline 6 & evil & 30 & 5.03 \\
\hline 7 & sin & 23 & 3.86 \\
\hline 8 & police & 21 & 3.52 \\
\hline 9 & crime & 20 & 3.36 \\
\hline 10 & unfair & 19 & 3.19 \\
\hline 11 & position & 18 & 3.02 \\
\hline 12 & responsible & 18 & 3.02 \\
\hline 13 & greed & 15 & 2.52 \\
\hline 14 & shortcut & 15 & 2.52 \\
\hline 15 & bully & 14 & 2.35 \\
\hline 16 & gift & 14 & 2.35 \\
\hline 17 & prison & 14 & 2.35 \\
\hline 18 & corruption & 13 & 2.18 \\
\hline 19 & selfish & & 2.01 \\
\hline
\end{tabular}

\section{Similarity Analysis}

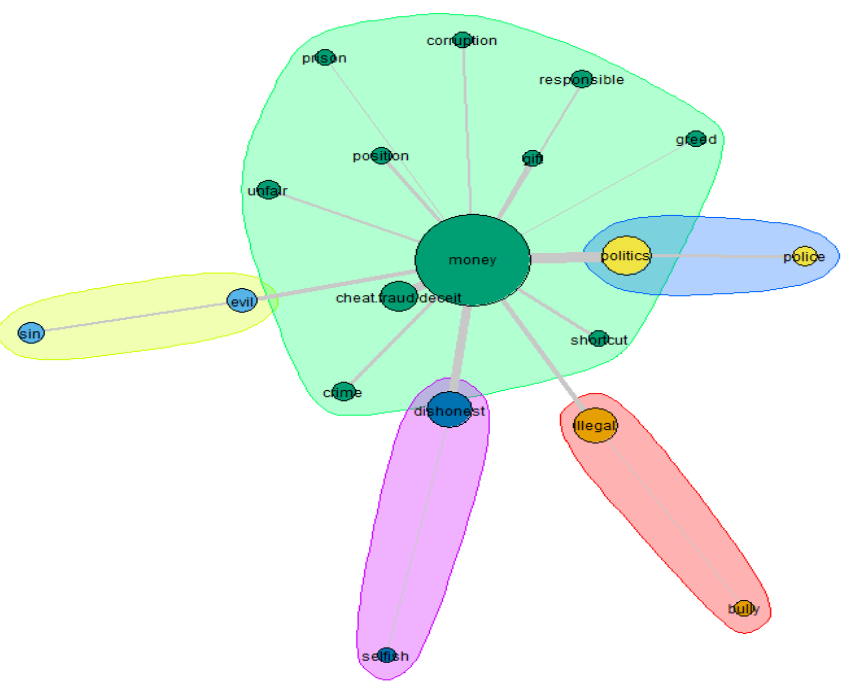

Figure 1: Results of the similarity analysis of corruption 
The tree-shaped graph generated using Iramuteq showed only one nucleus with the element "money" in the central position and five representation clusters highlighted in different shapes. See Figure 1. This indicates that "money" is one of the most frequently used elements with high co-concurrence with the most significant elements (marked by the thickness of the nodes) such as "politics", "illegal", "dishonest", and "evil". "Money" is the normative character that represents corruption. The co-occurrence elements illustrate the thought process of the respondents is primarily centered on the interconnection between these elements.

In the main cluster, "money" is co-occurring with the most significant elements e.g. "cheat", "unfair", "position", "gift", "shortcut" and "crime". This demonstrates that respondents understand that corruption is a form of cheating, crime, irresponsible act, and it is a shortcut in problem-solving. Money that was used in the form of corruption creates unfairness and it is usually done by people who hold positions because of greed. Corruption could also be in the form of gifts. Prison was mentioned implying that the respondents understood the cost of corruption. The second cluster shows co-occurrence between "money", "politics" and "police". This representation is directed towards those who are holding public positions and specifically police. This might be due to either personal experience or people who are close to them dealing with police (e.g. see Singh, 2018) or influence from the media that report corruption cases associated with politicians (e.g. see Wright and Hope, 2018).

The third cluster, "money" is co-occurrence together with "illegal" and "bully". This could be interpreted as corruption involving the illegal use of money to bully. The Fourth cluster associates "dishonest" and "selfish" with money, which could be understood as people who are involved in corruption are dishonest and selfish. The fifth cluster, "money" was cooccurred with "evil" and "sin" indicating corruption is being considered from a moral perspective. However, a small circle of the two elements indicating only a few people socially represent corruption from a moral perspective. 


\section{Prototypical Analysis}

Table 2. Result of prototypical analysis of corruption

\begin{tabular}{lcclcr}
\hline \multicolumn{2}{l}{\begin{tabular}{l} 
Average rank of importance \\
\multicolumn{2}{c}{$<.67$}
\end{tabular}} & \multicolumn{3}{c}{ Average rank of importance $>2.67$} \\
\hline Elements & $\#$ & Rank & Elements & $\#$ & Rank \\
\hline Box 1: Central core & & & Box 2: First periphery \\
Money & 156 & 2.0 & Dishonest & 61 & 3.1 \\
Politics & 53 & 2.5 & Illegal & 44 & 2.8 \\
& & & Cheat/fraud/deceit & 36 & 2.9
\end{tabular}

\section{Box 3: Contrasting}

$\begin{array}{lll}\text { Evil } & 30 & 2.0 \\ \text { Crime } & 20 & 2.6 \\ \text { Position } & 18 & 2.1 \\ \text { Corruption } & 13 & 2.6\end{array}$

\section{Box 4: Second periphery}

\begin{tabular}{lll} 
Sin & 23 & 2.8 \\
Police & 21 & 3.0 \\
Unfair & 19 & 3.3 \\
Responsible & 18 & 3.6 \\
Shortcut & 15 & 2.9 \\
Greed & 15 & 3.9 \\
Prison & 14 & 3.1 \\
Gift & 14 & 2.9 \\
Bully & 14 & 4.1 \\
Selfish & 12 & 4.0 \\
\hline
\end{tabular}

Table 2 illustrates the result of a prototypical analysis of the social representation of corruption among young people in Malaysia. The central core element for corruption is represented by the two words in Box 1, "money" and "politics". These are the elements that appear in the mind of the respondents immediately when asked about corruption. It is stable over time and agreed upon by most of the respondents. "Money" and "politics" explain how our respondents understood corruption and it serves as their group values and norms about corruption (Moliner \& Abric, 2015). Besides that, the association between these two elements with corruption is also non-negotiable. Moreover, these two elements could be considered deeply rooted in the collective memory of our respondents (Orosz, 2010).

Prototypical analysis generates two main peripheral groups, proximal peripheral systems, and far peripheral systems. Proximal peripheral systems represented by elements evoked from Box 2: First Periphery and Box 3: Contrasting. The first periphery element is represented by three words in Box 2, "dishonest", "illegal" and "cheat". Elements evoked have high frequencies and low importance levels. Box 3, the contrasting element represented by four words, "evil", "crime", "position", and "corruption". Elements evoked have low frequencies and high importance levels. These are the elements shared by the minority within the group (Abric, 2003). Typically, peripheral elements are numerous, many differences among group members, varying and unstable (Moliner \& Abric, 2015). The elements generated are related to group members' individual experiences, absorbs contradiction, and changes, also allows for group heterogeneity (Moliner \& Abric, 2015).

The main function of the proximal peripheral systems is to protect the central core system (Moliner \& Abric, 2015). This could be understood as e.g., dishonesty is cognitively used to 
protect the core, "money" that is used to define corruption. Besides that, respondents also associate illegal money with corruption. Mazar et.al (2008) found that people can be more dishonest when money is not involved. As "money" is the core of corruption, without the involvement of money, cheating is not seen as a corrupt act. As the elements are flexible and change easily based on environment and everyday experiences (Chundu et al., 2021) to support adaptation to reality (Salès-Wuillemin et al., 2020), it serves as a potential change zone (Aim et al., 2018) without needed to change the core. However, it could potentially change the core system in the long term (Granhag et al., 2017; Menezes et al., 2021).

Elements of far peripheral systems also referred to as the second periphery, were presented in Box 4. The second periphery element is represented by nine words, "sin", "police", "unfair", "responsible", "shortcut", "greed", "prison", "gifts", "bully", and "selfish". Elements that appeared in this box are low in frequencies and low in importance level. It is least useful in defining lay representation (Chundu et al., 2021). Hence, it will not be further discussed.

\section{Discussion}

The results from both similarities and prototypical analysis allows us to make five suggestions about anti-corruption education for young people. Firstly, young people in Malaysia socially represented corruption with the term's "money" and "politics" as the core of corruption. This result is consistent with similar lay representation studies carried out in Russia (Steklova \& Steklov, 2018) and Indonesia (Abraham \& Pradipto, 2016) where "money" was found to be in the core element. Despite cultural differences, this association illustrates that "money" is the deeply rooted reason why corruption happens (Orosz, 2010). Anti-corruption education must educate people about the method of corruption that could be done beyond money. Corruption could also happen when offered were done in form of e.g. gift-giving (Graycar \& Jancsics, 2016), sex (Jeffereys, 2006), favoritism (Truex, 2011).

Secondly, despite the cultural similarity, the lay representation study in Indonesia (Abraham \& Pradipto, 2016) does not find "politics" to be associated with corruption, while lay representation in Russia listed "power" as its element. This may be due to the current political instability in Malaysia and Russia. The elected government of Malaysia fell after less than 24 months in power (Ufen, 2021), making young people associate the fall with corruption in politics. This belief might be further strengthened by the urge from the former InspectorGeneral of Police, Hamid Bador, to investigate potential corruption that led to the fall of the government (Goh, 2021). Besides that, not to forget, our politicians are involved in various corruption and it is heavily reported in the media (Oxford Analytica, 2019). As politics appeared in the central core, it is very difficult to change this belief as it has become the "group identity" - association of corruption and politics. However, anti-corruption education must continue to provide examples of integrity and legal practices in politics.

Thirdly, there are seven distinct types of corruption: transactive, extortive, investive, defensive, nepotistic, autogenic, and supportive (Alatas, 1991). However, the social representation does not show that our young people fully understand all types of corruption. The elements such as "police" suggest that they might only understand the transactive types, where mutual arrangement between donor and recipient is to the advantage of and actively pursued by both parties using money. Therefore, anti-corruption must be educated about all types of corruption. 
Fourthly, young people do not show favorable attitudes towards corruption. This could be observed through unfavorable representation such as dishonesty, cheat, evil, and crime. The element "dishonest", despite high in occurrence frequency, respondents rank it in the lower importance level. All of this representation only appears in the peripheral system, indicating its flexibility in defining corruption and will change according to the social situation (Moliner \& Abric, 2015). This flexibility suggests that there is room for rationalization to act corruptly. Similarity analysis highlighted that fewer people socially represent corruption with moralityrelated terms such as "evil" and "sin". This might result from years-long religious and moral education in our education system (De Asildo \& Yasin, 2021). Anti-corruption education must not only focus on educating people that corruption is not acceptable behavior but emphasize that corruption is not acceptable regardless of any situation or circumstances. To measure the success of anti-corruption education, all the elements indicating it is unacceptable behavior must fall under the core elements to form a strong group identity of anti-corruption.

Fifth, all the elements do not show our young people understand the costs of corruption. The element "prison" only appeared in the second peripheral system which is not a significant element according to the TSR theory (Chundu et al., 2021). According to the cost-benefit analysis, understanding the cost of action could help to curb the action (Becker, 1968). Moreover, other effects of corruption e.g. on the economy, country growth, inequality, poverty, and undermining democracy were not part of the lay representation (Nichols and Robertson, 2017). Anti-corruption education needs to educate our young people about the effects of corruption.

The reader should bear in mind that the study gathered its data based on free association techniques and should only be considered as an exploratory method (Moliner \& Abric, 2015). This is because although free association allows us to explore the frequency and level of importance for each element, it does not provide a further understanding of e.g., the element "money". For example, money could be further interpreted as illegal money or corruption allows us to gain more money. Besides that, this study reported results based on majorityfemale respondents.

\section{Conclusion}

This study intends to make suggestions about the development of anti-corruption education in Malaysia. A survey to explore young people's lay representation toward corruption using the Theory of Social Representation was carried out. The data was obtained in Malay language and translated into English for reporting purposes. Three analyses; data coding, similarity, and prototypical analysis were carried out to answer the research question. The result of this study provides five considerations towards the development of anti-corruption education in Malaysia; (1) educate people about the concept of corruption that includes not only money exchange; (2) continue to provide examples of integrity and legal practices in politics; (3) educate people about all types of corruption, (4) emphasise that corruption is not acceptable regardless of any situation or circumstances and (5) educate people about the effects of corruption. Suggestions from this study could be used by anyone including the government, stakeholders, schools, and non-profit organizations who are interested in educating the public or creating anti-corruption awareness among young people in Malaysia. 


\section{Acknowledgments}

The authors greatly appreciate Professor Hew Gill for his inspiration and insightful ideas. This research is made possible with support from the Malaysian Anti-Corruption Agency (MACC) by providing the research team with data and ideas.

\section{References}

Abraham, J., \& Pradipto, Y. (2016). Corruption: Its Representations and Psychology in Indonesia. ACP/ACERP 2016 Official Conference Proceedings (ISSN: 2187-4743), 357369.

Abric, J. C. (2003). Méthodes d'étude des représentations sociales. Eres.

Aim, M. A., Decarsin, T., Bovina, I., \& Dany, L. (2018). Health and Social Representations: A Structural Approach. Special Issue: Epistemologies of Everyday Life, 27(1).

Alatas, S. H. (1991). Corruption: it's nature, causes, and functions. S. Abdul Majeed.

Assegaf, A. (2017). Curbing Corruption Through Tertiary Education in Indonesia and Japan. Journal of Social Science and Religion, 2(2), 254-273.

Bales, M. E., \& Johnson, S. B. (2006). Graph theoretic modeling of large-scale semantic networks. Journal of Biomedical Informatics, 39(4), 451-464.

Becker, G. S. (1968). Crime and Punishment: An Economic Approach. The Economic Dimensions of Crime.

Bernama. (2020). Anti-corruption module to be taught in schools, says MACC chief. Free Malaysia Today. https://www.freemalaysiatoday.com/category/nation/2020/09/02/anti-corruptionmodule-to-be-taught-in-schools-says-macc-chief/

Bidjari, A. F. (2011). Attitude and Social Representation. Procedia - Social and Behavioral Sciences, 30, 1593-1597. 10.1016/j.sbspro.2011.10.309

Brislin, R. W. (1970). Back-Translation for Cross-Cultural Research. Journal of Cross-Cultural Psychology, 55, 104-113. 10.1177/135910457000100301

Chundu, S., Allen, P. M., Han, W., Ratinaud, P., Krishna, R., \& Manchaiah, V. (2021). Social representation of hearing aids among people with hearing loss: an exploratory study. International Journal of Audiology, 1-15. 10.1080/14992027.2021.1886349

Danermark, B., Englund, U., Germundsson, P., \& Ratinaud, P. (2014). French and Swedish teachers' social representations of social workers. European Journal of Social Work, 17, 491-507. 10.1080/13691457.2013.829803

De Asildo, N., \& Yasin, M. (2021). 'Noble character' as a focus in Moral Education in Malaysia. In Social Studies Education in South and South East Asian Contexts. Routledge.

Dvoryanchikov, N., Bovina, I., Vikhristuck, O., \& Berezina, E. (2014). self-murder and selfmurderers in social representations of young russians: an exploratory study. Psichologija, 50, 33-48. 10.15388/Psichol.2014.50.4889

Ferrara, M., \& Friant, N. (2016). The application of a multi-methodology approach to a corpus of social representations. Qual Quant, 50, 1253-1271. 10.1007/s11135-015-0203-3

Gill, C. H. D., \& Berezina, E. (2020). School performance in three South East Asian countries: lessons in leadership, decision-making and training. European Journal of Training and Development, 45(2/3), 136-148.

Goh, N. (2021). Malaysian ex-police chief Abdul Hamid's expose makes waves but won't spark reforms: experts. South China Morning Post. https://www.scmp.com/weekasia/politics/article/3133047/malaysian-ex-police-chief-abdul-hamids-exposemakes-waves-wont 
Granhag, P. A., Bull, R., Shaboltas, A., \& Dozortseva, E. (2017). Psychology and Law in Europe: When West Meets East. Routledge.

Graycar, A., \& Jancsics, D. (2017). Gift Giving and Corruption. International Journal of Public Administration, 40(12), 1013-1023.

Haw, T. J., Kueh, J., \& Ling, S. W. S. (2020). Corruption and Growth in ASEAN Countries: A NonLinear Investigation. International Journal of Academic Research in Business and Social Sciences, 10(3), 347-369.

Jeffreys, E. (2006). Debating the legal regulation of sex-related bribery and corruption in the People's Republic of China. Routledge.

Kamaluddin, R., Nasir, R., Sulaiman, S., Khairudin, R., \& Zamani, Z. A. (2017). Validity and Psychometric Properties of Malay Translated Religious Orientation Scale-Revised among Malaysian Adult Samples. Akademika, 87(2), 133-144.

Kasim, A. C., \& Hoesni, S. M. (2021). Corruption and Islamization in Malaysia. International Journal Academic Research in Business and Social Sciences, 11(6), 1206-1220. 10.6007/IJARBSS/v11-i6/10256

Kollmannová, D. K. (2013). The Growth of Anti-Corruption Attitudes in Czech Marketing Communication and PR: Anti-Corruption Fight as Marketing Tool. Central European Business Review, 2(1), 15-20. 10.18267/j.cebr.34

Lee, C. Y., \& Yoshihara, H. (1997). Business ethics of Korean and Japanese managers. Journal of Business ethics, 16(1), 7-21.

Lee, L. T. (2018). Go to school to have an early start in the fight against corruption. The star online. https://www.thestar.com.my/opinion/letters/2018/12/14/go-to-school-tohave-an-early-start-in-the-fight-against-corruption

Mazar, N., Amir, O., \& Ariely, D. (2008). The dishonesty of honest people: A theory of selfconcept maintenance. Journal of marketing research, 45(6), 633-644.

Menezes, T., Maciel, S. C., Faro, A., Silva, L., \& Dias, C. (2021). Social representation of obesity: an analysis with students of middle and university education. Ciencias Psicológicas, 15(1), 1-15. 10.22235/cp. v15i1.2388

Moliner, P., \& Abric, J. C. (2015). Central core theory. In G. Sammut, E. Andreouli, G. Gaskell, \& J. Valsiner (Eds.), The Cambridge handbook of social representations (pp. 83-95). Cambridge University Press. 10.1017/СBO9781107323650.009

Mondragon, N. I., Sancho, N. B., Munitis, A. E., \& Santamaria, M. D. (2021). Exploring the social and emotional representations used by students from the University of the Basque Country to face the first outbreak of COVID-19 pandemic. Health Education Research, 36(2), 159-169. 10.1093/her/cyab006

Muhamad, N., \& Gani, N. A. (2020). A decade of corruption studies in Malaysia. Journal of Financial Crime, 27(2), 423-436. 10.1108/JFC-07-2019-0099

Muhiudeen, S. (2018). No-small-gift policy, please. The star online. https://www.thestar.com.my/business/business-news/2018/06/09/nosmallgiftpolicy-please

Ngui, Y., \& Wright, T. (2016). Malaysia Says Saudis Gave Prime Minister Najib Razak a \$681 Million 'Donation'. The wall street journal. https://www.wsj.com/articles/malaysiasattorney-general-najib-razak-received-681-million-personal-donation-from-saudiroyals-1453780909

Nichols, P. M., \& Robertson, D. C. (2017). Introduction and Overview: Bribery and the Study of Decision Making. In Thinking about Bribery Neuroscience, Moral Cognition and the Psychology of Bribery. Cambridge University Press. 10.1017/9781316450765.001 
Orosz, G. (2010). Social representation of competition, fraud and academic cheating of French and Hungarian citizens. University of Reims Champagne Ardenne.

Oxford Analytica. (2019). Malaysia's governing coalition will survive turbulence. Expert Briefings. 10.1108/OXAN-DB245334

Poeschi, G., \& Ribeiro, R. (2015). Everyday opinions on grand and petty corruption: a Portuguese study. In Corruption, Economic Growth and Globalization (pp. 73-86). ImprintRoutledge.

Polli, G. M., da Silveira, F. M., Magnabosco, F. M., dos Santos, F. M., Stella, G.H. S., Pinto, P. D., Zibetti, M. R., \& Apostolidis, T. (2021). Representations of food among vegetarians in Brazil: A psychosocial approach. International Journal of Gastronomy and Food Science, 24, 1-11. 10.1016/j.ijgfs.2021.100317

Salès-Wuillemin, E., Minondo-Kaghad, B., Oliveira, P. D., \& Clain, A. (2020). What is the role of Pôle Emploi? Crossed representations among job seekers and careers advisers: Between requests for help and types of support provision. Pratiques Psychologiques, 26(4), 347-362.

Sammut, G., \& Howarth, C. (2014). Social Representations. Springer. 10.1007/978-1-46145583-7_292

Satar, A. (2018). Corruption and Crime in Malaysia: Perception or Reality? Akhbar \& Associates.

Singh, S. (2018). Traffic cops detained over alleged RM800 bribe. The star online. https://www.thestar.com.my/news/nation/2018/09/06/traffic-cops-detained-overalleged-rm800-bribe/

Sousa, L. (2008). 'I Don't Bribe, I Just Pull Strings': Assessing the Fluidity of Social Representations of Corruption in Portuguese Society. Perspectives on European Politics and Society, 9(1), 8-23. doi.org/10.1080/15705850701825402

Steklova, Y., \& Steklov, V. (2018). Social representations of modern russian youth of the phenomenon "corruption". Economic and Social Development: Book of Proceedings, 2018, 791-800.

Suruhanjaya Pilihan Raya Malaysia. (2021). Semakan keputusan pilihan raya umum ke - 14 [Official GE14 Result for Pekan Parliament Seat]. Suruhanjaya Pilihan Raya Malaysia. https://keputusan.spr.gov.my/

Truex, R. (2011). Corruption, Attitudes, and Education: Survey Evidence from Nepal. World Development, 39(7), 1133-1142.

Ufen, A. (2021). The Downfall of Pakatan Harapan in Malaysia: Coalitions during Transition. Asian Survey, 61(2), 273-296.

Upton-McLaughlin, S. (2013). The Art of Giving Gifts in China. The China cultural corner. Retrieved 2021, from https://chinaculturecorner.com/2013/10/30/giving-gifts-inchina/

Voelklein, C., \& Howarth, C. (2005). A review of controversies about social representations theory: a British debate. Culture and psychology, 11 (4). pp. Cultural psychology, 11(4), 431-454. https://core.ac.uk/download/pdf/93123.pdf

Wright, T., \& Hope, B. (2019). Billion Dollar Whale: The Man Who Fooled Wall Street, Hollywood, and the World. Hachette Books. 